М.В. Дудко ${ }^{1}$, Н.О. Королюк ${ }^{1}$, П.В. Опенько ${ }^{2}$

${ }^{1}$ Харківський національний університет Повітряних Сил ім. I. Кожедуба, Харків

${ }^{2}$ Начіональний університет оборони Украйни ім. I. Черняховського, Київ

\title{
УЗАГАЛЬНЕНИЙ АЛГОРИТМ ПЛАНУВАННЯ МАРШРУТУ РОЗВІДУВАЛЬНОГО ПОЛЬОТУ БЕЗПІЛОТНОГО ЛІТАЛЬНОГО АПАРАТУ ІЗ ВИКОРИСТАННЯМ НЕЧІТКИХ ЛОГІЧНИХ СИСТЕМ
}

Для задачі планування маршруту розвідувального польоту безпілотного літального апарату (БПЛА) у статті запропоновано використання евристичних методів, які враховують практику, досвід, інтуїцію, знання особи, щзо приймає рішення. Обтрунтована доцільність представлення значень окремих прогнозованих факторів з використанням математичного апарату нечітких множин. Вибір доцільної стратегії польоту БПЛА запропоновано здійснювати за допомогою моделі прийняття рішень з врахуванням стратегії рефлексивного управління, яка адаптується до реальних умов, конфліктних ситуацій, що можуть складатися в ході ведення повітряної розвідки і характеризуватись факторами стохастичної та нестохастичної невизначеності. Визначений склад формалізованих знань в ході виконання процедури концептуалізації неформального опису сукупності знань щзодо планування маршруту розвідувального польоту БПЛА в умовах невизначеності. Розроблений узагальнений алгоритм планування марируту БПЛА, який представляється сукупністю взаємопов'язаних операџій і процедур та враховує склад знань про проиес планування марируту польоту БПЛА, визначення доцільної стратегії польоту БПЛА. Сукупність знань запропоновано формалізувати із використанням математичного апарату нечітких логічних множин інтервального типу 2. Узагальнений алгоритм планування маршруту БПЛА з урахуванням невизначеності забезпечує комплексну обробку знань щзодо планування розвідувального польоту БПЛА, які формалізовані із використанням математичного апарату нечітких логічних систем інтервального типу 2, та знань щзодо визначення доцільної стратегії польоту БПЛА в ході ведення повітряної розвідки, формалізованих за допомогою нечіткого виведення для нечітких логічних систем інтервального типу 2.

Ключові слова: планування мармруту польоту, інтервальні нечіткі множини типу 2, особа, щуо приймає рішення, нечітка логічна система, формалізачія знань.

\section{Вступ}

Постановка проблеми. Оборонний характер воєнної доктрини Збройних Сил України (ЗСУ) висуває високі вимоги до процесу підготовки військ та стану системи управління, елементів бойової готовності [1]. Готовність до відбиття агресії противника шляхом ведення оборонних дій - головне призначення Збройних Сил України. В ході підготовки та ведення бойових дій одним 3 вирішальних умов організації та успішного виконання найважливіших завдань $є$ зосередження основних зусиль розвідки на головному напрямку для своєчасного виявлення засобів масового ураження, високоточної зброї, головного угруповання противника, бойових порядків, артилерії, мінометів, резервів, пунктів управління. Отже найважливішою задачею командування при оборонному характері воєнної доктрини стає постійне спостереження за противником, яке повинно забезпечити своєчасний, організований перехід військ з мирного на воєнний стан. Основна роль при цьому відводиться розвідці [2]. Особа, що приймає рішення, (ОПР) не здатна прийняти правильне рішення, ефективно застосувати вогневі засоби, якщо вона не організує безперервну активну і цілеспрямовану розвідку, не отримує достовірні відомості про противника. Застосування сучасної техніки, підготовленого особового складу, наявність переваги над противником у силах і засобах не забезпечує досягнення успіху. Повітряна розвідка $є$ однією 3 найважливіших умов успіху бойових дій авіації та інших родів військ, завданням якої $є$ своєчасне забезпечення штабів, командування повними і достовірними даними про противника. В теперішній час безпілотні літальні апарати (БПЛА) розглядаються як ефективний та надійний засіб повітряної розвідки. Завдяки оперативному наданню повної, достовірної інформації про противника досягається успішність ведення бойових дій.

Складність у прийнятті обгрунтованого рішення щодо побудови доцільного маршруту польоту обгрунтовується застосуванням БПЛА в умовах обмежень, льотних та технічних можливостей апарата, наявністю засобів ураження противника та 
передбачає множину варіантів маршруту польоту БПЛА. Досвід практичного застосування літальних апаратів показав, що обмеження, умови, вимоги, зовнішні фактори суперечать один одному, створюючи невизначеність при наданні пріоритету будьякому з варіантів маршруту польоту [2-4].

Отже формування рекомендацій щодо планування маршрутів розвідувального польоту БПЛА на етапі планування повітряної розвідки є актуальним завданням.

Аналіз останніх досліджень і публікацій. Підвищення ефективності повітряної розвідки з БПЛА тактичної ланки є достатньо поширеною науковою проблематикою, яку розглядає ряд вітчизняних та зарубіжних науковців. У працях [3-4] розглядаються математичні моделі, які мають за мету підвищення ефективності розвідки з БПЛА шляхом визначення оптимального маршруту польоту за допомогою розрахунку ймовірності виконання завдань розвідки. Проте досвід застосування БПЛА в операції об'єднаних сил на сході України свідчить про необхідність врахування факторів, які впливають на ефективність розвідувальних операцій з БПЛА. Необхідно брати до уваги загрози та обмеження природного та технічного характеру [5-7], які суттєво впливають на кінцевий результат польотного завдання. В [8-9] не враховано факторів впливу зовнішнього середовища, які, у свою чергу, вносять зміни у вихідний результат планування. Наведені фактори впливу враховуються із високим ступенем суб'єктивізму особи, яка планує маршрут польоту. В [10] метод планування вибирається в залежності від завдання, яке стоїть перед системою, конкретного випадку, а також у залежності від обчислювальних можливостей відповідного обладнання (апаратної частини системи).

Висока вразливість БПЛА від різних факторів бойової обстановки, низька “інтелектуальність” в автономному режимі через відсутність таких людських якостей, як оперативне прийняття рішення, можливість перенесення основних зусиль на нові, більш важливі об'єкти, здатність здійснювати заходи для введення в оману противника, є сьогодні нерозв'язними проблемами, що знижують ефективність бойового застосування сучасних БПЛА та потребують врахування вищеперерахованих факторів на етапі планування повітряної розвідки [11-14].

Отже, як показав аналіз публікацій за темою дослідження, описана вище задача, має важливість для науки і практики, залишається актуальною та потребує свого вирішення.

Мета статті. Розробка узагальненого алгоритму планування маршруту розвідувального польоту БПЛА з врахуванням тактичних умов ведення розвідки, впливу зовнішнього середовища при використанні математичного апарату нечітких множин.

\section{Виклад основного матеріалу}

Відомі методи планування маршруту польоту БПЛА можна розділити на дві категорії: детерміновані і евристичні. Детерміновані методи базуються на строгих математичних моделях при певній послідовності обчислень. Евристичні методи шукають рішення усередині деякого підпростору можливих прийнятних рішень, що сформовані експертами в даній предметній області. Знайдене евристичними методами рішення формально може не бути оптимальним, однак воно є найкращим з точки зору досвіду, знань особи, що приймає рішення (ОПР), повсякденної практики вирішення завдань повітряної розвідки.

Прийняття рішення відносно вибору доцільних стратегій польоту розвідувального БПЛА в ході ведення повітряної розвідки базується на способі представлення знань (моделі подання знань) і методі формалізації знань, що визначають модель прийняття рішень, яка, в свою чергу, включає множину конфліктних ситуацій. Фактори, що формують конфліктні ситуації, можуть мати природу як стохастичної так і нестохастичної невизначеності. Оскільки розглядається операція між двома сторонами, то до факторів нестохастичної невизначеності, слід віднести фактори, які мають природу поведінкової невизначеності. Фактори, що впливають на планування маршруту, мають нечіткі (розмиті) границі, а для деяких елементів інтервалу не можна з повною впевненістю стверджувати належність цих елементів однозначно до інтервалу. Представлені подібним чином дані формалізуються, як правило, з використанням математичного апарату нечітких множин [15-23].

На формування множин конфліктних ситуацій, які можуть реально виникнути, будуть впливати різні фактори, які мають поведінкову невизначеність, а саме:

- використання противником оперативної побудови, ешелонів, рубежів, які невідомі для сторони A;

- вибір заходів протидії, які для сторони $A \epsilon$ невизначеними;

- можливість проведення демонстраційних дій;

- влив зовнішнього середовища.

Намагання врахувати змінні, що відповідають зазначеним факторам, відповідає меті адаптації моделі до множини реальних конфліктних ситуацій, які можуть скластися в ході ведення повітряної розвідки. Це і буде відповідати меті сторони $A$, що оперує, по прийняттю доцільних рішень в конфліктних ситуаціях, які реально складаються. Звичайно, розгляд адаптації моделі до реальних ситуацій доцільно розглядати за час, який не перевищує термін проведення повітряної розвідки сторони $B$ стороною $A$. 
Отже, проблема полягає в адаптації заздалегідь розробленої моделі прийняття рішення з врахуванням стратегії рефлексивного управління, представлення знань і методів формалізації знань до зміни множини конфліктних ситуацій, які можуть складатися в ході ведення повітряної розвідки. Тому актуальним $є$ розробка методичного підходу щодо адаптації розробленої моделі прийняття рішення до реальних умов, які можуть скластися в ході ведення повітряної розвідки. При прийнятті управлінських рішень при визначені доцільних стратегій польоту БПЛА в ході планування повітряної розвідки формування множини конфліктних ситуацій визначається нечітким описом інформаційного ресурсу суб'єктів управління. Виходячи з того, що кінцеві цілі сторін протилежні, в якості моделі протидії протилежних сторін слід розглядати матричну антагоністичну гру двох осіб з нульового сумою, яка описується кортежом виду

$$
\Gamma_{C}=\left(\{A, B\}, S_{A}, S_{B},\{\bar{S}\}_{\overline{S \in} S_{A} \times S_{B}}\right),
$$

де $\{A, B\}-$ множина гравців;

$S_{A}, S_{B}$ - множина стратегій дій гравців $\{A, B\}$;

$\{\bar{S}\}_{\overline{S \in} S_{A} \times S_{B}}$ - множина конфліктних ситуацій, як декартовий добуток множин стратегій дій гравців.

Для будь-якої конфліктної ситуації маємо

$$
\begin{gathered}
\bar{S}=S_{i} \times S_{j} ; \bar{S} \in S_{A} \times S_{B} ; S_{A}=\bigcup_{i=1}^{n} S_{i} ; S_{B}=\bigcup_{j=1}^{m} S_{j} ; \\
W_{A}(\bar{S})=-W_{B}(\bar{S}),
\end{gathered}
$$

де $W_{A}(\bar{S}), W_{B}(\bar{S})$ - функції виграшу гравців $A, B$.

Гра компромісів (1) обмін інформацією між гравцями не передбачає, бо всяке повідомлення щодо стратегій дій, яке може бути отримано однією із сторін відносно наміру другої, може тільки приводити до збільшення виграшу однієї з них. Гра (1) задається матрицею

$$
C=\left\|C_{i j}\right\|, i=\overline{1, n}, j=\overline{1, m} .
$$

Розмірність матриці визначається розмірністю множин конфліктних ситуацій $\{\bar{S}\}_{\overline{S \in} S_{A} \times S_{B}}$, а іï елементи $C_{i j}$-функції виграшу сторони $A$, що оперує. Кожній конфліктній ситуації $\bar{S}$ відповідає пара чистих стратегій $\left\{S_{i}, S_{j}\right\}$. Можемо говорити про те, що управлінська діяльність ОПР в інтересах сторони $A$ пов'язана з обльотом наземних об'єктів розвідки. Сторони в операції мають протилежні інтереси, тому для формування множини доцільних стратегій польоту БПЛА $S_{A}$ слід виходити 3 того, що сторона $A$ має в своєму розпорядженні $N_{A}$ об'єктів, яким необхідно спланувати маршрут польоту над об'єктами $M_{B}$ сторони $B$. Сторона $B$ має в своєму розпорядженні $N_{B}$ об'єктів та планує здійснити перешкодження $M_{A}$ об'єктам сторони $A$. Така постановка розподілу ресурсів $N_{A}, N_{B}$ між об'єктами $M_{A}, M_{B}$ дозволяє в поняття стратегії $S_{i}, i=\overline{1, n}$ та $S_{j}, j=\overline{1, m}$ вкласти можливі стратегії виконання завдань наступного змісту:

$$
\begin{aligned}
& N_{A}^{\left(S_{i}\right)}=N_{A}, \forall S_{i} \in S_{A}, i=\overline{1, n} ; \\
& N_{B}^{\left(S_{j}\right)}=N_{B}, \forall S_{j} \in S_{B}, j=\overline{1, m} ; \\
& M_{A}=\left\{m_{A}^{(s)}\right\}, s=\overline{1, S} ; M_{B}=\left\{m_{B}^{(r)}\right\}, r=\overline{1, R} ; \\
& N_{A}=\sum_{r=1}^{R} n_{m_{B}^{(r)}}^{\left(S_{i}\right)}, N_{B}=\sum_{s=1}^{S} n_{m_{A}^{(s)}}^{\left(S_{j}\right)},
\end{aligned}
$$

де $m_{A}^{(s)}, m_{B}^{(r)}$ - відповідно $s$-х та $r$ - х об'єктів сторін $A$ та $B \quad 3$ витрачанням відповідно $n_{m_{A}^{(s)}}^{\left(S_{j}\right)}, \quad n_{m_{B}^{(r)}}^{\left(S_{i}\right)}$ одиниць ресурсів сторони $B$ та $A$ у відповідності до стратегіï $S_{j}$ i $S_{i}$.

В подальшому будемо виходити з того, що сторона $A$ забезпечена засобами для виявлення об'єктів сторони $B$, але ці засоби сторони $A$ здатні лише забезпечити “якісну сторону” при формуванні рішення, що означає доцільність введення лінгвістичної змінної для опису адаптації моделі (рис. 1) до зазначених вище факторів [24-27].

Таким чином, вибір доцільної стратегії польоту БПЛА для кожного визначеного малого проміжку часу пропонується здійснювати за допомогою моделі прийняття рішень 3 врахуванням стратегії рефлексивного управління, що адаптується до реальних умов, зміни множин конфліктних ситуацій, що можуть складатися в ході ведення повітряної розвідки і характеризуватись факторами стохастичної та нестохастичної невизначеності. Урахування факторів, природа яких описується нестохастичною невизначеністю, дозволяє приймати раціональні за ефективністю рішення з рівнем довіри $\alpha$-функцій приналежності їм відповідних нечітких змінних лінгвістичних змінних та прийнятим рівнем недомінованості елементів множин носіїв, що відповідають рівню довіри.

Виходячи з визначеного в ході виконання процедури концептуалізації неформального опису сукупності знань про планування маршруту польоту БПЛА в умовах невизначеності у вигляді відповідного поля знань визначимо склад формалізованих знань:

- формалізовані знання про прогнозовану операцію, тактичні умови проведення розвідки, вплив 
зовнішнього середовища;

- формалізовані знання про найбільш важливі ті об'єкти, які приймають участь в системі управління протилежної сторони та інформаційній протидії в операції;

- формалізовані знання про прогнозовану систему ППО противника;

- формалізовані знання щодо визначення доцільної стратегії польоту БПЛА з урахуванням виду операції.
Виходячи зі складу знань про процес планування маршруту польоту БПЛА, формалізованих 3 використанням математичного апарату нечітких логічних множин інтервального типу 2, про процес визначення доцільної стратегії польоту БПЛА був розроблений узагальнений алгоритм планування маршруту БПЛА 3 урахуванням невизначеності, який представляється сукупністю взаємопов'язаних операцій і процедур, представлених на рис. 1.

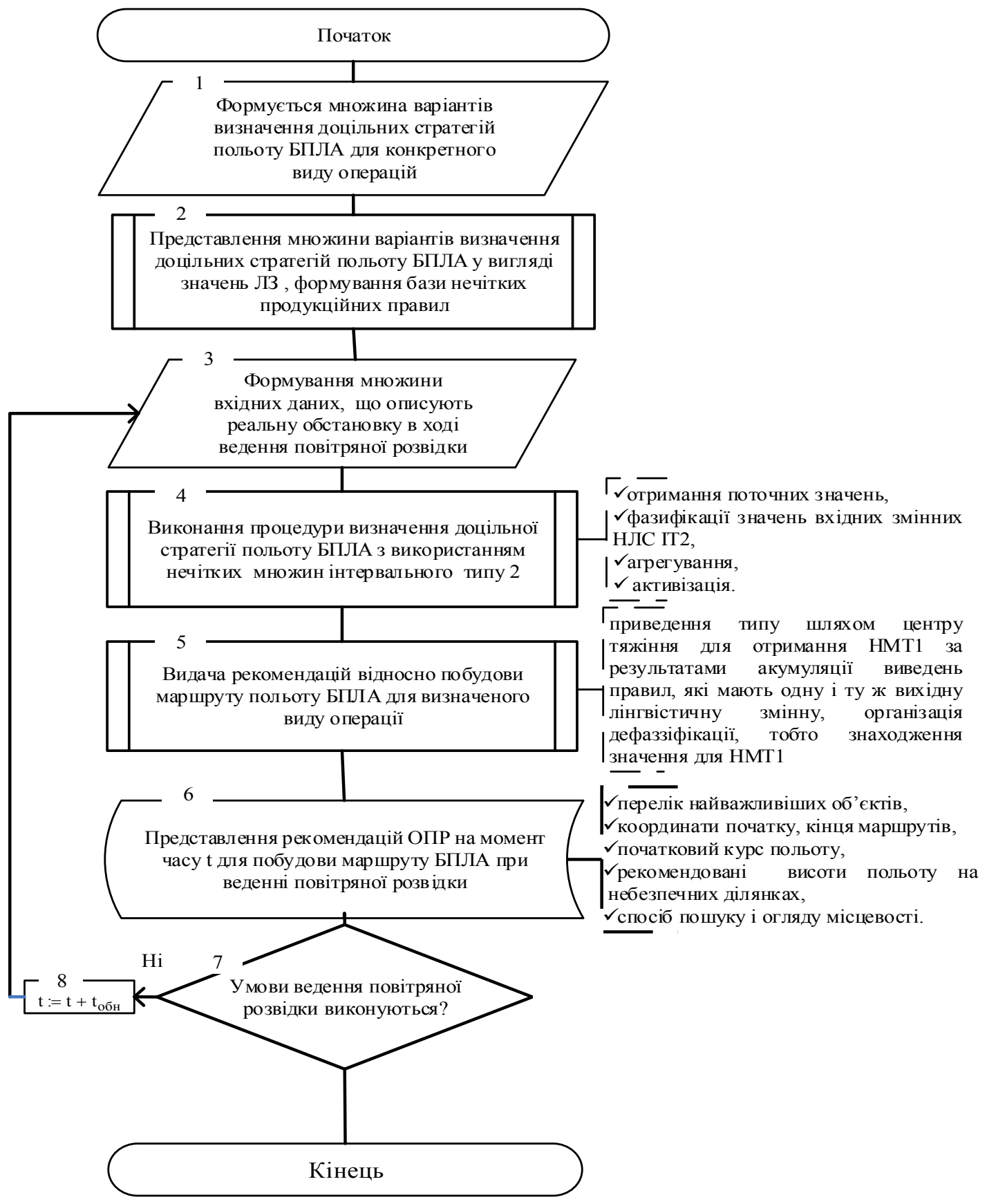

Рис. 1. Схема узагальненого алгоритму планування маршруту розвідувального польоту БПЛА із використанням нечітких логічних систем Джерело: розроблено авторами за даними [12-13]. 
Розглянемо опис узагальненого алгоритму відповідно до основних етапів згідно його структури:

1) формується множина варіантів визначення доцільних стратегій польоту БПЛА для конкретного виду операцій, що враховують тактичні умови проведення розвідки, вплив зовнішнього середовища на дальність польоту БПЛА, $C_{p}=\left\{c_{1}^{p}, c_{2}^{p}, \ldots, c_{m}^{p}\right\}$ для кожного $V_{i}^{p}$-го варіанта операції в ході підготовки до ведення повітряної розвідки;

2) задаються значення множини варіантів визначення доцільних стратегій польоту БПЛА у вигляді значень лінгвістичних змінних з використанням інтервальних нечітких множин інтервального типу 2, формується база нечітких продукційних правил;

3) формується множина вхідних даних $O_{t}=\left\{o_{i}\right\}, i=1 . . N$, сформованих засобами загальновійськової, космічної, агентурної розвідки на момент часу $t$ ( $N$ - кількість визначених факторів), що описують реальну обстановку в ході ведення повітряної розвідки;

4) виконується процедура визначення доцільної стратегії польоту БПЛА з використанням нечітких логічних систем інтервального типу 2;

5) виконується процедура видачі рекомендацій відносно побудови маршруту польоту БПЛА для визначеного виду операції на момент часу $t_{l}$ у вигляді комбінації переліку найважливіших об'єктів розвідки, точки початку, кінця маршруту польоту, початковий курс польоту, рекомендованої висоти польоту на небезпечних ділянках, способу пошуку і огляду місцевості.

\section{Висновки}

Таким чином, досліджено, що для задачі планування маршруту розвідувального польоту БПЛА доцільно використовувати евристичні методи, які враховують практику, досвід, інтуїцію, знання ОПР при веденні повітряної розвідки. Значення окремих прогнозованих факторів доцільно представляти 3 використанням математичного апарату нечітких множин.

Актуальним питанням $є$ розробка методичного підходу щодо адаптації розробленої моделі прийняття рішення до реальних умов, які можуть скластися в ході ведення повітряної розвідки. Вибір доцільної стратегії польоту БПЛА для кожного визначеного малого проміжку часу пропонується здійснювати за допомогою моделі прийняття рішень з врахуванням стратегії рефлексивного управління, яка адаптується до реальних умов, зміни множин конфліктних ситуацій, які можуть складатися в ході ведення повітряної розвідки і характеризуватись факторами стохастичної та нестохастичної невизначеності.

3 визначеного в ході виконання процедури концептуалізації неформального опису сукупності знань про планування маршруту польоту БПЛА в умовах невизначеності у вигляді відповідного поля знань визначений склад формалізованих знань.

Виходячи зі складу знань про процес планування маршруту польоту БПЛА, формалізованих 3 використанням математичного апарату нечітких логічних множин інтервального типу 2, про процес визначення доцільної стратегії польоту БПЛА був розроблений узагальнений алгоритм планування маршруту БПЛА із врахуванням невизначеності, який представляється сукупністю взаємопов'язаних операцій і процедур.

Узагальнений алгоритм планування маршруту БПЛА забезпечує комплексну обробку знань щодо процесів планування польоту БПЛА, формалізовану 3 використанням математичного апарату нечітких логічних систем інтервального типу 2, знань щодо визначення доцільної стратегії польоту БПЛА в ході підготовки до ведення повітряної розвідки, формалізованих за допомогою нечіткого виведення для нечітких логічних систем інтервального типу 2.

\section{Список літератури}

1. Указ Президента України “Про Стратегію воєнної безпеки України від 25 березня 2021 року” [Електронний ресурс]. - Режим доступу: https://zakon.rada.gov.ua/laws/show/121/2021.

2. Пермяков О.Ю. Метод формалізації знань про процес визначення доцільної стратегії польоту безпілотних літальних апаратів в ході підготовки до ведення повітряної розвідки на основі нечітких логічних систем / О.Ю. Пермяков, М.В. Дудко, Н.О. Королюк // Військова кібернетика та системний аналіз. - 2020. - № 2(38). - С. 12-18.

3. Аналіз застосування безпілотних літальних апаратів в сучасних збройних конфліктах та АТО на Сході України / В.В. Камінський, В.В. Тюрін, О.А. Коршець, Н.О. Королюк // Наука і оборона. - 2017. - № 3(4). - С.4-8.

4. Степанов Г.С. Погляди щодо проблемних питань застосування Повітряних Сил в протиповітряній обороні / Г.С. Степанов, В.В Камінський, М.А. Павленко // Наука і техніка Повітряних Сил Збройних Сил України. - 2018. № 1(30). - С. 18-23. https://doi.org/10.30748/nitps.2018.30.03.

5. Камінський В.В. Боротьба з повітряним тероризмом має починатися з землі / В.В. Камінський // Наука і техніка Повітряних Сил Збройних Сил України. - 2014. - № 1(14). - С. 16-23.

6. Обгрунтування сучасного підходу щодо автоматизації процесів прийняття рішень по управлінню авіацією / Н.О. Королюк, О.В. Першин, Т.О. Грідньова, С.О. Шевченко // Збірник наукових праць Харківського національного vніверситету Повітряних Сил. - 2019. - № 1(59). - С. 32-39. https://doi.org/10.30748/zhups.2019.59.04. 
7. Олизаренко С.А. Нечеткие множества типа 2. Терминология и представление / С.А. Олизаренко, Е.В. Брежнев, А.В. Перепелица // Системи обробки інформації. - 2010. - № 8(89). - С. 131-140.

8. Тимочко О.І. Метод оцінки ступеня небезпеки нештатних ситуацій у повітряному просторі / O.I. Тимочко, П.П. Зуєв // Наука і техніка Повітряних Сил Збройних Сил України. - 2017. - № 1(26). - С. 49-53. https://doi.org/10.30748/nitps.2017.26.10.

9. Амелин К.С. Адаптивная мультиагентная операционная система реального времени / К.С. Амелин, М.В. Баклановский, О.Н. Граничин // Стохастическая оптимизация в информатике. - 2013. - № 1(9). - С. 3-16.

10. Бережний А.О. Методи рішення завдань планування поведінки агентів в інтелектуальних системах підтримки прийняття рішень / А.О. Бережний, М.Ю. Сорока // Збірник наукових праць Харківського національного університету Повітряних Сил. - 2019. - № 4(62). - С. 18-24. https://doi.org/10.30748/zhups.2019.62.02.

11. Королюк Н.О. Процедура формалізації даних, які використовуються при описі процесу управління рухом повітряних об'єктів / Н.О. Королюк, Р.В. Корольов, О.А. Коршець // Збірник наукових праць Харківського національного університету Повітряних Сил. - 2017. - № 4(53). - С. 103-106.

12. Метод формалізації знань про процес планування маршруту польоту безпілотних літальних апаратів на основі інтервальних нечітких множин типу 2 / М.В. Дудко, Н.О. Королюк, Ю.І. Полонський, О.А. Коршець // Збірник наукових праць Харківського національного університету Повітряних Сил. - 2020. - № 3(65). - С. 36-42. https://doi.org/10.30748/zhups.2020.65.05

13. Олизаренко С.А. Интервальные нечеткие множества типа 2. Терминология, представление, операции / С.А. Олизаренко, А.В. Перепелица, В.А. Капранов // Системи обробки інформації. - 2011. - № 2(92). - С. 39-45.

14. Korolyuk N. An approach to prediction of the telecommunication network quality parameters under the conditions of non-stochastic uncertainty / N. Korolyuk // Telecommunications and Radio Engineering - 2017. - № 76(11). - P. $1027-1032$. https://doi.org/10.1615/telecomradeng.v76.i11.80.

15. Saatya T. Structures in decision making: On the subjective geometry of hierarchies and networks / T. Saatya // European Journal of Operational Research. - 2009. - № 3(199). - P. 867-872.

16. Королюк Н.О. Удосконалення програмного забезпечення комплексів засобів автоматизації при розпізнаванні типу повітряного об’єкта / Н.О. Королюк, В.В. Синявський, Д.О. Хаустов // Системи озброєння і військової техніки. 2017. - № 1(49). - С. 122-125.

17. Теоретические основы автоматизации процессов выработки решений в системах управления / В.Е. Ярушек, В.П. Прохоров, А.В. Мишин, Б.Н. Судаков. - Х.: ХУВС, 2011. -355 с.

18. Ротштейн О.П. Діагностика на базі нечітких відношень в умовах невизначеності: монографія / О.П. Ротштейн, Г.Б. Ракитянська. - Вінниця: УНІВЕРСУМ Вінниця, 2006. - 275 с.

19. Hybrid model of knowledge for situation recognition in airspace / M.A. Pavlenko, A.I. Timochko, N.A. Korolyuk, M.Y. Gusak // Automatic Control and Computer Sciences. - 2014. - № 48(5). - P. 257-263. https://doi.org/10.3103/s0146411614050083.

20. Selecting a model of unmanned aerial vehicle to accept it for military purposes with regard to expert data / A. Alimpiev, P. Berdnik, N. Korolyuk, E. Korshets, M. Pavlenko // Eastern-European Journal of Enterprise Technologies. - 2017. № 1(9). - P. 53-60. https://doi.org/10.15587/1729-4061.2017.93179.

21. Hagras H. Introduction to Interval Type-2 Fuzzy Logic Controllers - Towards Better Uncertainty Handling in Real World Applications [Electronic resource] / Hani Hagras, Christian Wagner // Systems, Man and Cybernetics Society. - 2009. № 27. - 2009. - Available at: https://ieeesmc.org/newsletters/back/2009_06/SMC-Hagras.html.

22. Mendel J.M. Interval Type-2 Fuzzy Logic Systems Made Simple / J.M. Mendel, R.I. John, Feilong Liu // IEEE Transactions on Fuzzy Systems. - 2006. - № 6. - P. 808-821.

23. Пермяков О.Ю. Інформаційно-телекомунікаційні технології і сучасна збройна боротьба / О.Ю. Пермяков, Н.О. Королюк // Науково-технічна конференція молодих учених “Актуальні проблеми інформаційних технологій”. Київ, 20-21 листопада 2018 р. - С. 5-6.

24. Mendel J.M. Standard Background Material About Interval Type-2 Fuzzy Logic Systems [Electronic resource] / J.M. Mendel, H. Hagras, R.I. John // IEEE CIS Standards Committee. - Available at: http://ieee-cis.org/technical/standards/.

25. Wu H. Uncertainty Bounds and Their Use in the Design of Interval Type-2 Fuzzy Logic Systems / H. Wu, J.M. Mendel // IEEE Transactions on Fuzzy Systems. - 2002. - № 5. - P. 622-639. https://doi.org/10.1109/tfuzz.2002.803496.

26. Wu D. Enhanced Karnik-Mendel Algorithms / D. Wu, J.M. Mendel // IEEE Transactions on Fuzzy Systems. - 2009. № 4. - P. 923-934. https://doi.org/10.1109/tfuzz.2008.924329.

27. Mendel J.M. On centroid calculations for Type-2 Fuzzy Sets / J.M. Mendel // Applied and Computational Mathematics. - 2011. - № 1. - P. 88-96.

\section{Відомості про авторів:}

\section{Дудко Марина Валеріївна}

науковий співробітник

Харківського національного університету

Повітряних Сил ім. І. Кожедуба,

Україна

https://orcid.org/0000-0002-2010-1779
Надійшла до редколегії 30.04.2021

Схвалена до друку 12.05.2021

Information about the authors:

\author{
Maryna Dudko \\ Research Associate \\ of Ivan Kozhedub Kharkiv \\ National Air Force University, \\ Kharkiv, Ukraine \\ https://orcid.org/0000-0002-2010-1779
}


Королюк Наталія Олександрівна

кандидат технічних наук заступник начальника кафедри

Харківського національного університету

Повітряних Сил ім. І. Кожедуба,

Харків, Україна

https://orcid.org/0000-0002-2865-5899

\section{Опенько Павло Вікторович}

кандидат технічних наук

начальник науково-дослідного відділу

Інституту авіації та протиповітряної оборони

Національного університету

оборони України ім. I. Черняховського,

Київ, Україна

https://orcid.org/0000-0001-7777-5101
Natalia Korolyuk

Candidate of Technical Sciences

Deputy Chief of Department

of Ivan Kozhedub Kharkiv

National Air Force University,

Kharkiv, Ukraine

https://orcid.org/0000-0002-2865-5899

\section{Pavlo Openko}

Candidate of Technical Sciences

Chief of Scientific Research Department

of Institute of Aviation and Air Defense

of National Defense University

of Ukraine named after Ivan Cherniakhovskyi,

Kyiv, Ukraine

https://orcid.org/0000-0001-7777-5101

\title{
ОБОБЩЕННЫЙ АЛГОРИТМ ПЛАНИРОВАНИЯ МАРШРУТА РАЗВЕДЫВАТЕЛЬНОГО ПОЛЕТА БЕСПИЛОТНОГО ЛЕТАТЕЛЬНОГО АППАРАТА С ИСПОЛЬЗОВАНИЕМ НЕЧЕТКИХ ЛОГИЧЕСКИХ СИСТЕМ
}

\author{
М.В. Дудко, Н.А. Королюк, П.В. Опенько
}

Для задачи планирования маршрута разведывательного полета беспилотного летательного аппарата (БПЛА) в статье предложено использование эвристических методов, которые учитывают практику, опыт, интуицию, знаний лица, принимающего решение. Обоснована целесообразность представления значений отдельных прогнозируемых факторов с использованием математического аппарата нечетких множеств. Выбор целесообразной стратегии полета БПЛА предложено осуществлять с помощью модели принятия решений с учетом стратегии рефлексивного управления, адаптирующейся к реальным условиям, конфликтных ситуаций, которые могут складываться в ходе ведения воздуш-ной разведки и характеризоваться факторами стохастической и нестохастической неопределенности. Определен состав формализованных знаний в ходе выполнения процедуры концептуализации неформального описания совокупности знаний по планированию маршрута разведывательного полета БПЛА в условиях неопределенности. Разработан обобщенный алгоритм планирования маршрута БПЛА, который представляется совокупностью взаимосвязанных операций и процедур и учитывает состав знаний о процессе планирования маршрута полета БПЛА, определения целесообразной стратегии полета БПЛА. Совокупность знаний предложено формализовать $c$ использованием математического аппарата нечетких логических множеств интервального типа 2. Обобщенный алгоритм планирования мар-шрута БПЛА с учетом неопределенности, обеспечивает комплексную обработку знаний по планированию разведыва-тельного полета БПЛА, которые формализованы с использованием математического аппарата нечетких логических систем интервального типа 2, и знаний по определению целесообразной стратегии полета БПЛА в ходе ведения воз-душной разведки, формализованных с помощью нечеткого вывода для нечетких логических систем интервального типа 2.

Ключевые слова: планирование маршрута полета, интервальные нечеткие множества типа 2, лицо, принимающее решение, нечеткая логическая система, формализация знаний.

\section{GENERALIZED ROUTE PLANNING ALGORITHM FOR A RECONNAISSANCE FLIGHT OF AN UNMANNED AERIAL VEHICLE USING FUZZY LOGIC SYSTEMS}

M. Dudko, N. Korolyuk, P. Openko

The article proposes the use of heuristic methods based on practice, experience, intuition, and knowledge of the decision maker for planning the route of an unmanned aerial vehicle (UAV) reconnaissance flight. The expediency of representing the values of individual predicted factors using the mathematical apparatus of fuzzy sets has been substantiated. It is proposed to define an appropriate UAV flight strategy using a decision-making model according to the reflexive control strategy, that adapts to real conditions, conflict situations during aerial reconnaissance and are characterized by factors of stochastic and nonstochastic uncertainty. The composition of formalized knowledge in the course of performing the procedure of conceptualizing the informal description of the body of knowledge for planning the route of a reconnaissance flight of an UAV under conditions of uncertainty has been determined. A generalized algorithm for planning a UAV route has been developed. It is represented by a set of interrelated operations and procedures and is based on the body of knowledge about the process of planning a UAV flight route, determining an appropriate UAV flight strategy. The body of knowledge is proposed to be formalized using the mathematical apparatus of fuzzy logical sets of interval type 2. The generalized algorithm for planning the UAV route, according to uncertainty, provides a comprehensive knowledge processing about planning a reconnaissance flight of UAVs that is formalized using the mathematical apparatus of fuzzy logical systems of interval type 2, and knowledge by definition of expedient UAV flight strategy during aerial reconnaissance, formalized using fuzzy inference for fuzzy logical systems of interval type 2.

Keywords: flight route planning, interval fuzzy sets of type 2, decision maker, fuzzy logical system, knowledge formalization. 